

\title{
Losing Covid-19 Fight: How the Ghanaians Attitude Eroded Government's Effort
}

Peter Nalaw Yatimue

To Link this Article: http://dx.doi.org/10.6007/IJARBSS/v10-i9/7746

DOI:10.6007/IJARBSS/v10-i9/7746

Received: 11 June 2020, Revised: 12 July 2020, Accepted: 16 August 2020

Published Online: 22 September 2020

In-Text Citation: (Yatimue, 2020)

To Cite this Article: Yatimue, P. N. (2020). Losing Covid-19 Fight: How the Ghanaians Attitude Eroded Government's Effort. International Journal of Academic Research in Business and Social Sciences. 10(9), 345358.

Copyright: (c) 2020 The Author(s)

Published by Human Resource Management Academic Research Society (www.hrmars.com)

This article is published under the Creative Commons Attribution (CC BY 4.0) license. Anyone may reproduce, distribute, translate and create derivative works of this article (for both commercial and non-commercial purposes), subject to full attribution to the original publication and authors. The full terms of this license may be seen at: http://creativecommons.org/licences/by/4.0/legalcode

Vol. 10, No. 9, 2020, Pg. 345 - 358

http://hrmars.com/index.php/pages/detail/IJARBSS

JOURNAL HOMEPAGE

Full Terms \& Conditions of access and use can be found at http://hrmars.com/index.php/pages/detail/publication-ethics 


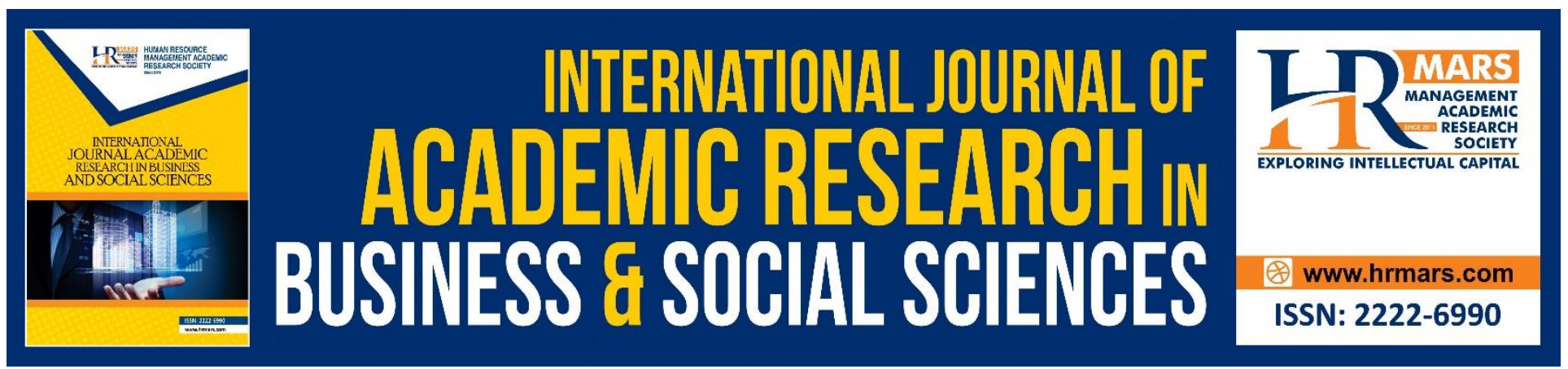

\title{
Losing Covid-19 Fight: How the Ghanaians Attitude Eroded Government's Effort
}

\author{
Peter Nalaw Yatimue \\ Department of Management, Faculty of Business, Universiti Kuala Lumpur, University's Address \\ 1016, Jalan Sultan Ismail, 50250 Kuala Lumpur \\ Email: enquiries@unikl.edu.my/peternalaw@gmail.com
}

\begin{abstract}
Coronavirus (Covid-19) is a deadly disease caused by an acute respiratory syndrome coronavirus 2 (SARS-CoV-2) and was discovered in Wuhan, China in late 2019. The World Health Organisation declared Covid-19 a public health emergency of international concern on 30 January 2020 and a pandemic on 11 March 2020. From the onset, Ghana was among the leading countries boldly confronting and containing the spread of the Covid-19 pandemic but later slipped downwards and is now among the top ten (10) countries with high case counts of Covid-19 in Africa. This paper presents comprehensive exploratory insights into Ghana's Covid-19 situation, focusing on how Ghanaians attitude has frustrated the government's effort in the fight against Covid-19. The paper was structured as follows: section one presents the background, section two discusses the outbreak of Covid-19 in Ghana, section three delves into the government's immediate and aggressive response to curbing the spread of Covid-19, section four details how the government addressed the socioeconomic impact of Covid-19 on Ghanaians livelihoods and businesses, section five discusses the Ghanaians attitude as a major driving factor for the upsurge of Ghana's Covid-19 case counts, section six discusses the waning war against Covid-19 in Ghana, and section 7 provided some possible recommendations to combating the pandemic.
\end{abstract}

Keywords: Coronavirus, Covid-19, SARS-COV-2, Ghana, Ghanaians, Attitude, Lockdown, Accra, Kumasi.

\section{Background}

Coronavirus (or Covid-19) is a deadly disease that was first detected in Wuhan city in the Peoples Republic of China in December 2019. Covid-19 is caused by an acute respiratory syndrome coronavirus 2 (SARS-CoV-2) (Rothan \& Byrareddy, 2020; Shereen et al., 2020). On 30 January 2020, the World Health Organisation (WHO) declared Covid-19 a public health emergency of international concern and a pandemic on 11 March 2020 (Sohrabi et al., 2020). Covid-19 spreads mainly through person-to-person contact when a favourable medium is created for the virus to be transferred from the infected person to the uninfected person contained in tiny droplets in the event that the infected person coughs, sneezes, or talks. 
INTERNATIONAL JOURNAL OF ACADEMIC RESEARCH IN BUSINESS AND SOCIAL SCIENCES Vol. 10, No. 9, 2020, E-ISSN: 2222-6990 @ 2020 HRMARS

The rate of infection or spread of Covid-19 is rapid - and it can infect thousands of people within a few seconds worldwide. As of Thursday, July 23, 2020, at 07:15 GMT, the total confirmed cases of Covid-19 around the globe in 188 countries were 15, 382,483; the total number of deaths was 630,369 , whereas the total number of recoveries were 9,356,371, respectively (Worldometer, 2020). Symptoms of Covid-19 include fever, cough, fatigue, shortness of breath, and loss of sense of smell. There are not yet vaccines for the treatment of Covid-19. The only best-known approach which has been recommended by health experts such as WHO for fighting Covid-19 is by prevention, including keeping or maintaining social distance, wearing of nose masks, regular handwashing with soap under running water for at least, twenty (20) seconds, among others.

From the onset, Ghana was among the leading countries boldly confronting and containing the spread of the Covid-19 pandemic but later slipped downwards and is now one of the top ten countries with high case counts of Covid-19 in Africa. The purpose of this paper is to provide preliminary insights into understanding Covid-19 pandemic situation in Ghana by highlighting how Ghanaians attitude has contributed to the upsurge of Ghana's Covid-19 numbers to as high as twentynine thousand, six hundred and seventy-two $(29,672)$ as of Thursday, July 23, 2020, 07:15 GMT (Worldometer, 2020).

The paper is divided into seven sections as follows: section one presents the background, section two discusses the outbreak of Covid-19 in Ghana, section three delves into the government's immediate and aggressive response to curbing the spread of Covid-19, section four details how the government addressed the socioeconomic impact of Covid-19 on Ghanaians livelihoods and businesses, section five discusses the Ghanaians attitude as a major driving factor for the upsurge of Ghana's Covid-19 case counts, section six details the waning war against Covid-19 in Ghana, and section 7 enumerates some recommendations for combating the Covid-19 pandemic in Ghana. This research seeks to fulfil the following objectives:

- To describe how the Ghana government responded to the Covid-19 pandemic outbreak and the strategies for preventing and containing the spread of the virus in Ghana.

- To highlight the Ghana government's interventions to addressing the socioeconomic impact of Covid-19 on Ghanaians livelihoods and businesses.

- To elaborate on how Ghanaians attitude frustrated the government's efforts resulting in the upsurge of Ghana's Covid-19 case counts.

- To critique some of the government's weaknesses in the fight against Covid-19 in Ghana.

- To suggest how the Ghana government can overcome the bottlenecks in its fight against the spread of the Covid-19 pandemic.

\section{The Outbreak of Covid-19 Pandemic in Ghana}

Ghana recorded its first case of Covid-19 on the 12 March 2020, with two persons testing positive for the virus. The two cases were all imported by travelers from Norway and Turkey (Dogbevi, 2020). The outbreak of the Covid-19 pandemic in Ghana came a day just after WHO declared the virus a pandemic. Ghanaians' initial reaction to the news of the outbreak of the Covid-19 pandemic was very explosive, causing nervousness, fear, and panic. Two major issues were of great concern to Ghanaians: one, that there was not yet a vaccine discovered for the treatment of the virus, and two, that Ghana's healthcare system is underdeveloped and under resourced to combat Covid-19 pandemic. 
INTERNATIONAL JOURNAL OF ACADEMIC RESEARCH IN BUSINESS AND SOCIAL SCIENCES Vol. 10, No. 9, 2020, E-ISSN: 2222-6990 @ 2020 HRMARS

Before the Covid-19 pandemic outbreak, Ghana had only two medical centres where suspected cases of coronavirus can be tested - that is, the Noguchi Memorial Institute for Medical Research located in Accra and Kumasi Centre for Collaborative Research. It was envisaged that these two centres were woefully inadequate to meet the testing requirements of all the suspected cases if Ghana's case counts rise. Indeed, this was exactly so as severe pressure was mounted on these two centres when contact tracing commenced and case counts increased. Due to huge volumes of suspected cases, the blood samples that were collected for testing suffered undue delays in the delivery of the results. It took about 3-7 days for the test results of blood samples to be released and even took longer (2-3 weeks) when the case counts escalated.

It was a difficult moment for both the government and Ghanaians. The huge infrastructural deficits compared to Ghana's population of more than thirty million people was a bigger challenge for the country to confront the Covid-19 pandemic head-front. Given the extent of constraints that the developed countries like Italy, China, UK, Germany, and the US whose healthcare systems are sophisticated and advanced faced amid the Covid-19 pandemic, thinking of how Ghana was going to cope or survive this deadly pandemic was a great nightmare to every Ghanaian.

As a result, health experts and the Ghana Medical Association (GMA) called on the government to close all Ghana's borders with immediate effect to neighboring countries a temporal measure to prevent further importation of the virus into the country. There were also several calls on the government to initiate a 'lockdown' as a strict measure to lower the spread of the Covid-19 (Anyorigya, 2020). Meanwhile, the Ministry of Health (MoH) had already initiated the contact tracing process for the two infected persons for testing.

\section{Government's Immediate and Aggressive Response}

Ghana's confirmed cases of Covid-19 rose from two (2) to about one hundred and thirty-seven (137) with four (4) deaths within the first three (3) weeks. As a result, the call by the GMA on the government to declare a nationwide 'lockdown' became intense and was reechoed by the opposition political

parties, the civil society groups, the clergy, concerned citizens, and/or pressure groups.

In response, His Excellency the President of the Republic of Ghana, Nana Addo Dankwa AkufoAddo on Friday, 27 March 2020, announced a 2-week partial lockdown in two regions of Ghana - that is, Greater Accra and Greater Kumasi which were identified by the Ministry of Health as the 'epicentre' for the spread of the virus (Ansah, 2020). The affected cities in these regions were Greater Accra, Greater Kumasi, Tema, and Kasoa. Except for few businesses which operated in essential services such as pharmaceutical industries and food value chains, all other businesses were temporarily closed including all public gatherings. Funerals, schools, and universities, religious and political activities, night clubs, sporting activities, among others were all put on hold, subject to review. The partial lockdown took effect from Monday, 30 March 2020, and was extended for another week and officially ended on 20 April 2020 (Adebayo, 2020).

The government's swift response to the outbreak of the Covid-19 pandemic and subsequent closure of Ghana's borders and the imposition of restrictions on the movement of persons (lockdown) within the 'hotspot' areas positioned Ghana ahead of the fight against the Covid-19 pandemic. To speed and enhance the testing capacity, the government of Ghana provided funding for immediate construction and refurbishment of additional disease prevention and control units and testing centres in all the teaching hospitals around the country. Within a few weeks, more than ten (10) more 
INTERNATIONAL JOURNAL OF ACADEMIC RESEARCH IN BUSINESS AND SOCIAL SCIENCES Vol. 10, No. 9, 2020, E-ISSN: 2222-6990 @ 2020 HRMARS

testing centres were being added to the existing two across all the sixteen regions of Ghana. Blood samples from other regions that were flown by a drone to Kumasi and Accra for testing were now being tested within the respective regions. At least, testing capacity was no longer an issue. The test samples were now released just within forty-eight (48) hours, easing pressure on the first two (2) centres significantly.

The next challenge for Ghana was how to enhance the contact tracing to curb the spread of the virus. What the government did was to quickly form the Covid-19 contact tracing task force to locate and trace all suspected contacts of infected persons for their blood samples to be taken for testing. One hundred (100) pick-up vehicles and two thousand, five hundred $(2,500)$ tablets were purchased for the contact tracing exercise. Indeed, this measure helped to lower the spread of the virus significantly at the initial stage of its outbreak. To further ease the pressure or lessen the burden on the health workers, additional health workers including one thousand $(1,000)$ community health workers and one thousand (1,000) voluntary health workers were employed (Davlo, 2020).

Notwithstanding, the government supported the domestic companies that were operating in different production lines with an amount of one million dollars $(\$ 1 \mathrm{M})$ to diversify their productions and manufacture locally-made personal protective equipment (PPEs) such as face masks, head covers, surgical scrubs, gowns, sanitizers and detergents (Ghanaweb, 2020). Three million, six hundred thousand face masks $(3,600,000)$ were being produced with a daily production capacity of one hundred and fifty thousand $(150,000)$. This measure was not only proactive but also aggressive in addressing the challenges of high demand for PPEs and other essential medical supplies which were now in short supply as they had become the most essential commodities amid the Covid-19 pandemic globally.

The government also distributed three hundred and fifty thousand nose masks $(350,000)$, five hundred and fifty-eight thousand, six hundred and fifty $(558,650)$ examination gloves to all the health facilities across the country. Additionally, one thousand $(1,000)$ reusable goggles, twenty thousand $(20,000)$ cover-alls, seven thousand $(7,000) \mathrm{N}-95$ respirators, five hundred (500) waterproof gumboots, two thousand $(2,000)$ reusable face shields, two thousand $(2,000)$ gallons of hand sanitizers, ten thousand $(10,000) 100 \mathrm{ml}$ pieces of hand sanitizers, and five hundred $(500)$ shoe covers were distributed. Besides, the government embarked on nationwide disinfection or fumigation of all public places including markets, schools, police precincts, ministries, departments and agencies (MDAs), all in a bid to curtail the spread of Covid-19 pandemic (Ghanaweb, 2020). These efforts are commendable.

To motivate the hardworking health workers and nurses who have put their lives on the line of duty by providing the various forms of treatment to Covid-19 patients, the government paid the contact tracers GHC150 per person per day as allowances which are not part of their basic pay. Three months of tax-free salaries were paid to all health workers in addition to fifty percent basic salary payment to only frontline health workers and nurses. Furthermore, an insurance package of three hundred and fifty thousand Ghanaian Cedis $(\mathrm{GH} C 350,000)$ was announced for every frontline health worker. Free transportation was also provided to nurses who commute to work within Accra and Kumasi Metropolis. During the three weeks of partial lockdown, one hundred Ghanaian Cedis (GHC100) daily allowances were paid to all security officers who were deployed to enforce the lockdown rules and other Covid-19 safety protocols. 
INTERNATIONAL JOURNAL OF ACADEMIC RESEARCH IN BUSINESS AND SOCIAL SCIENCES Vol. 10, No. 9, 2020, E-ISSN: 2222-6990 @ 2020 HRMARS

\section{Addressing the Socioeconomic impact of Covid-19 on Ghanaian Livelihoods and Businesses}

The government's commitment to fighting the Covid-19 pandemic was not focused only on the health aspect but also on the economic impact of the pandemic on Ghanaians businesses and livelihoods. As a consequence, the government absorbed the water bills of all Ghanaian households and light bills of all consumers whose consumption rate were within 0-50 kilowatt-hour for three (3) months whereas those whose consumption rate was higher than 50 kilowatt-hours were given fifty percent discount for three months (Musungu, 2020). This incentive package was meant to ease the economic burden on Ghanaians due to the Covid-19, so, the government extended it for another three (3) months.

To further support Ghanaians, especially the poor and the vulnerable, the government established Covid-19 National Trust Fund and President Akufo-Addo and the Vice President Alhaji Dr. Muhammadu Bawumia donated their three (3) months full salaries into the Fund as seed money. All the ministers of state followed the President's and the Vice President's example by donating two months of their full salaries into the Trust Fund while all the deputy ministers donated fifty percent (50\%) of their two (2) months salaries into the Fund. This Fund aims to support and revive the Ghanaian micro, small, and medium scale businesses.

Since its establishment, donations have been pouring in from various sources such as from individuals, corporations, religious groups, and not-for-profit organisations, both home and abroad. The Trust Fund is being managed by an independent board of trustees headed by the immediate past Chief Justice, Sophia Akufo. The main task of the board of trustees is to receive all donations and disburse them equitably to all deserving Ghanaians. Similarly, the government established the Coronavirus Alleviation Program (CAP) with seed money of one billion Ghanaian Cedis (GHC1bn). A bill was passed in parliament to source for additional funding to support the Ghanaian businesses and households as a Covid-19 recovery measure to reduce job losses, ease the hardship on Ghanaians and promote domestic industrial outputs (Dixon, 2020).

Other government interventions include the reduction of interest rate by two percent (2\%), one and a half percent (1.5\%) reduction in Policy Pate rate, and two percent (2\%) reduction in reserve requirement. Additionally, six (6) months moratoriums of principal repayments were granted for the airline and hospitality industries. Provision of daily hot meals for all the vulnerable persons who could not feed during the partial lockdown and provision of dried and packaged foods for more than four hundred thousand $(400,000)$ poor homes in the affected areas of the partial lockdown was crucial intervention measures taken by the government to reduce the socioeconomic impact of Covi-19 on Ghanaians' businesses and livelihoods.

\section{Ghanaians Attitude - a Major Driving Factor for the upsurge of Ghana's Covid-19 Case Counts}

When President Nana Addo Dankwa Akufo-Addo was sworn into the high office as the President of the Republic of Ghana on 7 January 2017, he called on all Ghanaians to be citizens. 'I ask you to be citizens: citizens, not spectators; citizens, not subjects; responsible citizens building your communities and our nation' (Asante, 2017). If there was any better time for Ghanaians to demonstrate that they were responsible citizens, it would be during this era when the Covid-19 pandemic has besieged the world, including Ghana. Sadly, this has not been the case, or perhaps, Mr. Akufo-Addo's call fell into the deaf ears. The Ghanaians' initial reaction to the outbreak of the Covid19 pandemic in the country nearly created some false impression that people were conscious of the situation and its consequences on their health and lives. Far from it - the reverse was the case. 
INTERNATIONAL JOURNAL OF ACADEMIC RESEARCH IN BUSINESS AND SOCIAL SCIENCES Vol. 10, No. 9, 2020, E-ISSN: 2222-6990 @ 2020 HRMARS

The closure of borders for instance and the imposition of a partial lockdown that restricted all the public gatherings including religious activities was meant to lower and contain the spread of the Covid-19 pandemic. However, the partial lockdown revealed the true attitude of Ghanaians which was very disturbing and regrettable. While many Ghanaians complied with the lockdown rules and Covid-19 safety protocols, a larger proportion of Ghanaians wantonly violated the lockdown rules with impunity. Some pastors were caught holding church services with more than one hundred (100) people contrary to the lockdown rules that no public gathering was to exceed twenty-five (25) persons. The gross disrespect for the state and executive powers of the President of the Republic of Ghana was too glaring to be ignored. In other words, it leaves much to be desired.

The Ministry of Health and President Akufo-Addo jointly advised Ghanaians to wear nose masks and maintain social distance when in public in compliance with the recommendation by WHO as these were the most effective measures to preventing the Covid-19. Unfortunately, many Ghanaians refused to wear nose masks or maintain social distance during the partial lockdown and after the lockdown, even when at public places. The security officers who were deployed to enforce the safety protocols and lockdown rules were heavily criticized and denigrated by the public who claimed that the security officers applied arbitrary force on Ghanaians who violated the laws. To calm the situation down and reduce the complaints that the government was using the police and the military to brutalise or punish Ghanaians for mere violation of the lockdown and Covid-19 safety protocols, some hardworking security officers were quickly withdrawn from their duty posts.

The Ghanaians attitude was portrayed at its extreme when most Ghanaians who were suspected to have encountered infected persons refused to allow the contact tracers to take their blood samples for testing for the virus. Rumours had it that these individuals were misinformed by certain unpatriotic and ignorant citizens that their blood samples could be used for 'rituals' by the government, not for testing for Covid-19 as they were made to believe. This allegation is too ridiculous and defies logic for anybody to understand. This high level of superstition, ignorance, and illiteracy cast a bad image on Ghana as a country that is widely hailed internationally as a champion of democracy, rule of law and respect for the fundamental rights of humans and the beacon of hope for Africa.

Too recently, the Ministry of Information has disclosed that most Ghanaians totaling about twenty percent (20\%) still do not believe that Covid-19 exists (Ghanaweb, 2020). The worst is a good number of Ghanaians ignorantly believe that dark-skinned persons (or Africans) are resistant to Covid-19 - they can neither be infected nor get killed by the Coronavirus. Still, some believe that their belief in God guarantees them protection against the virus - that is, Covid-19 cannot infect or kill them. It then raises the bigger question of whether those who have been infected or died from Covid-19 do not believe in God or they were just sinners. Given this uncalled attitude, how will anyone expect the Ghana government to succeed in its fight against the Covid-19 pandemic?

Indeed, the lackadaisical attitude of Ghanaians undoubtedly frustrated the fight against the Covid-19 pandemic in every respect, making it much more complex to curb and contain the spread of the virus. It was unfortunate that many Ghanaians hurriedly condemned the current Second Deputy Speaker of Parliament, Honourable Alban Kingsford Sumani Bagbin when he suggested that Ghanaians should be shown the dead bodies of persons who died from Covid-19 live on the Televisions to proof that the virus was real (Ansah, 2020; Darwish, Ahmed, \& Pahi, 2020). 
INTERNATIONAL JOURNAL OF ACADEMIC RESEARCH IN BUSINESS AND SOCIAL SCIENCES Vol. 10, No. 9, 2020, E-ISSN: 2222-6990 @ 2020 HRMARS

... I want to see on Television some evidence of death because when you state that this number of people are dead but they are not seeing anything like that it will not give them the shock of their life. I believe in shock therapy. We need shock therapy to wake them up from slumber and make them know.

Bagbin was not wrong, at least. But the important question we should be asking is whether showing the dead bodies live on the Television is the best solution to addressing Ghanaians' attitudinal canker. Certainly not! We do not need any better evidence than what we have already seen and heard from around the world about the havoc that the Covid-19 pandemic is wreaking on human lives and businesses, not excluding Ghana. Possibly, the sudden death of Kwadwo Owusu Afriyie (Sir John), who was the Chief Executive Officer of Ghana Forestry Commission until his demise, and former General Secretary of the ruling New Patriotic Party (NPP) on 1 July 2020 after contracting Covid-19 will be enough but painful evidence for all doubting Ghanaians, including Alban Baghin to believe that Covid-19 is real. To borrow the words of the first President of the Republic of Ghana Dr. Kwame Nkrumah, any anyone or Ghanaian who still does not believe that Covid-19 exists or is real can only be suffering from intense myopia or acute deafness.

The negative attitude of Ghanaians was and, still, been portrayed in many ways. For example, many people have refused to disclose or are hiding their Covid-19 status. One of the reasons that could account for this undesirable phenomenon of people refusing or fear to reveal their Covid-19 status is due to the stigmatisation the Ghanaians have subjected the Covid-19 recovered patients through. However, the danger of hiding Covid-19 status far outweighs the stigmaisation and we cannot afford the luxury of overlooking it or lose sight of its danger to us as a country. Besides frustrating the Covid-19 fight or making the fight against Covid-19 very difficult, hiding of Cocid-19 status pre-exposes others to the virus. Perhaps, this misbehaviour might have accounted for the escalation of Ghana's Covid-19 case counts as we see it today. Regrettably, stigmatisation has become another deadly virus that Ghana must face and overcome.

Understandably, many Ghanaians are uneducated and so, are uninformed. What gives us a cause to worry is the refusal of even the members of parliament to disclose their Covid-19 status when some of them were tested positive for the virus. As if that was not enough, these members still attended parliament sessions and mingled their colleague members without any regard for the danger their presents pose to them and their families, friends, and the public. The simple reason is that the infected members of parliament think that their absence from parliament could expose them and let people discover they are the ones who tested positive for Covi-19. The Ministry of Health and the Ministry of Information also indicated that some Ghanaians refused to isolate or quarantine themselves when they were tested positive for the Covid-19 while others escaped or fled the quarantine or isolation centres for no apparent reasons.

It was also reported that some frontline nurses and health workers accepted bribes from travelers who were placed in quarantined/isolation and assisted them to escape or run from the quarantine/isolation centres. To date, no effort has been made by the Ministry of Health, Ghana Health Service nor the government to investigate or ascertain the veracity of these allegations so that offenders can be punished to serve as a deterrent to others.

Interestingly, as the government shared foods to the poor and the vulnerable individuals during the partial lockdown, some unscrupulous Ghanaians in their bid to thwart or discredit the government circulated fake news and videos on social media such as the YouTube. People posted 
INTERNATIONAL JOURNAL OF ACADEMIC RESEARCH IN BUSINESS AND SOCIAL SCIENCES Vol. 10, No. 9, 2020, E-ISSN: 2222-6990 @ 2020 HRMARS

unwholesome foods that were purported to be the hot meals shared by the government to the poor citizens. It looked like the opportunity had presented itself for some desperate political actors, mainly the opposition group to level huge allegations against the government. There were several allegations that the foods meant for the poor were only shared with individuals who belonged to the party of the ruling government. Contrary to these baseless allegations, the fact remained that the foods were shared by the National Disaster Management Organisation (NADMO) and faith-based religious leaders (that is, the Christian and the Muslim leaders who have no political interest whatsoever). Besides, foods were shared exclusively based on need, not on political affiliations. Other interesting allegations were that people accused those who were involved in the sharing of foods to have stolen some of the foods and sold them in the open markets.

What further crippled Ghana's fight against the Covid-19 was politicisation of the pandemic, triggered by the opposition parties. Politics is inevitable in our daily lives and we do not expect it to be absent in bad times like this. Whereas divergent views do help in the discussing of important national issues, nonetheless, politics in Ghana often ended up reducing very important national issues like the Covid-19 pandemic political battle which does not benefit anyone in the long run. Politics in Covid-19 was irresponsible and needless, to say the least. To some political opponents, the Covid-19 pandemic had created a very happiest and favourable grounds for them to launch their attack on the government and sting it with the deadliest venom. They are of high hopes and view that doing so will make the government very weak, helpless, and unattractive, and above all, unpopular in the sight of Ghanaians so that they can gain a political advantage.

A clear case in point was the allegations made by the General Secretary of the largest opposition political party, the National Democratic Congress (NDC), Johnson Asiedu Nktetia that the partial lockdown was a grand scheme by President Akufo-Addo's government to rig the upcoming general elections on 7 December 2020. While we cannot rightly refute this allegation, this comment a larger party like NDC was inappropriate and farfetched as far as the Covid-19 pandemic was concerned. Lockdowns have become the most effective approach used globally to confront the spread of Covid-19, and Ghana could not be an exception.

NDC as a party has close to forty-five percent of Ghanaians who voted for the party in the last 2016 general elections. Comments like this one made by Honourable Asiedu Nketia and other party leaders were more likely to send a wrong signal to their members and stir them against the government's resolve to fighting and combating the Covid-19 pandemic. This statement is too dangerous to consider and was condemnable. Some of these comments discourage people from observing Covid-19 safety protocols which in turn, put their lives in danger at the mercy of the virus as well as others who are too close to them.

Another frustration to Ghana's Covid-19 fight was the formation of NDC's Covid-19 response team by former President John Dramani Mahama, who is now the party's 2020 presidential candidate. It appears that Ghana's fight against Covid-19 was reduced to a political gimmick rather than a genuine commitment to combating the virus holistically. While the government had already established the National Covid-19 response taskforce to perform a special duty such as providing education to Ghanaians on how to safe of the Coronavirus, it served no purpose for anyone or opposition parties like NDC led by the former Mahama to form a parallel taskforce for the same tasks.

Predictably, rather than complementing the effort of the National Covid-19 taskforce to educate Ghanaians on how they can stay safe of the virus, the NDC's Covid-19 response team's first task was to accuse the government of poor handling of Covid-19 pandemic. What supposed to be a 
INTERNATIONAL JOURNAL OF ACADEMIC RESEARCH IN BUSINESS AND SOCIAL SCIENCES Vol. 10, No. 9, 2020, E-ISSN: 2222-6990 @ 2020 HRMARS

collective fight against the Covid-19 pandemic was now reduced to a mere political debate, leaving many uninformed Ghanaians confused about the pandemic. It must be pointed out that Ghana was wounded before the war against the Covid-19 pandemic had begun.

The internal and political struggle between the NDC as a party and the government on the other hand created a porous ground that did not help in the fight against the Coronavirus, hence the escalation of Ghana's Covid-19 case counts. One thing was clear, the political opponents exaggerated the Covid-19 pandemic situation and deliberately distorted facts thereby painting a gloomy picture to Ghanaians about what was happening on the grounds, contrary to the reality. Eventually, Ghana's Covid-19 fight was left in crisis.

\section{Waning War - Why the Government Got it all Wrong}

Certainly, the momentum and the zest with which Ghana started the Covid-19 fight is waning out. When addressing the nation on Covid-19 update, President Akufo-Addo made a strong statement that received international applause, most importantly by WHO boss, Dr. Tedros Adhanom Ghebreyesus. President Akufo-Addo said, ...' I assure you that we know what to do to bring our economy back to life. What we do not know how to do is to bring people back to life' (Pierre, 2020).

However, when we carefully scrutinise the rising Covid-19 case counts of Ghana, it is suggestive that President Akufo-Addo's government only paid lip service to showcase to the world that Ghana was on top of its fight against the Covid-19 pandemic with all the seriousness while this is not the case. Why will President Akufo-Addo impose a partial lockdown when Ghana's total confirmed cases of Covid-19 were just one hundred and thirty-seven (137) and four (4) deaths and turn around to lift the lockdown when the total confirmed cases had increased exponentially to one thousand and forty-two $(1,042)$ ? This move taken by President Akufo-Addo and the government raised several genuine concerns on whether Ghana was serious and committed to fighting the Covid19 pandemic at all.

We may have to exercise some level of caution when faulting President Akufo-Addo since the government's main reason was to save the Ghanaians' young businesses, given that more than seventy percent (70\%) of Ghanaian businesses are in the retail sector and were the most affected by the lockdown. Also, there were unnecessary complaints and accusations against the government when the lockdown was extended for another week. Many Ghanaians argued that extending the lockdown beyond the three weeks would have collapsed the Ghanaians' businesses and subject more than seventy percent (70\%) of the population into perpetual and abject poverty which in turn, can cause serious social problems such as arm robbery, teenage pregnancies, etc.

Incidentally, the areas affected by the partial lockdown (Greater Accra, Tema, and Greater Kumasi) are the business hub of Ghana, and if businesses in these areas collapse, the entire country will suffer greatly in terms of job losses and high unemployment. The attendance consequences are too numerous for the government and Ghanaians to bear.

However, since Ghana was not the only country to impose a partial lockdown, why were Ghanaians and the President worried? Conceivably, it was important for the government to consider the unique situation of Ghanaians and take measures that will not create much more difficult-tosolve problems (economic and social problems and hardships such as high unemployment rate) while trying to solve the health problems posed by the Covid-19 pandemic. Ending the partial lockdown within the three weeks was necessary for Ghanaians and the government to commence the economic recovery process well ahead of time. 
INTERNATIONAL JOURNAL OF ACADEMIC RESEARCH IN BUSINESS AND SOCIAL SCIENCES Vol. 10, No. 9, 2020, E-ISSN: 2222-6990 @ 2020 HRMARS

Some critics of the government find it difficult to accept the rush with which the government reopened the tertiary education institutions (universities and colleges), senior high schools and junior high schools for the final year students to take their exit examinations. It is widely believed that this move negatively affected the Covid-19 fight. It was laudable for the government to reopen schools for the final year university and college students to take their exit exams since they are mature enough to observe and adhere to all the Covid-19 safety protocols and can stay safe on campus. Contrarily, it was too early or premature to reopen the schools for the senior high and junior high final year students to take their exit examinations for the same reason that they are still young to observe Covid-19 safety protocols as is expected of them without being told to do so.

The government also failed in the Covid-19 fight by exhibiting sheer reluctance to punish and prosecute people who violated the safety protocols, especially when offenders belonged to the political class or were pro members of the ruling government. For example, Ghanaians expected more than just a resignation when the Deputy Trade's Minister, Carlos Ahenkorah who had contracted the Coronavirus embarked on a 'biological warfare' at a polling registration centre where many Ghanaians were gathered to register for the new voter identity cards to vote in the December 7, 2020, general elections.

The government's loud silence over this matter and many others when people in government broke the Covid-19 safety protocols and lockdown rules is worrying and can be likened to the popular story of Animal Farm by George Orwell that some animals are equal but some are more equal than others. By extension, the governments indifference and attitude certain persons when they fall fowl of the Covid-19 safety protocol rules suggests that some Ghanaians, mostly the politicians are more important than others. It was too obvious that the Covid-19 laws were only meant for or applicable when the poor were involved, not the rich, the ordinary citizens, not the politicians. How does President Akufo-Addo expect Ghanaians to be responsible citizens and observe the Covid-19 safety protocols while the politicians and people in government can break the same laws with impunity?

The memory of Ghanaians is still new concerning some pastors who were convicted for a jail term of four (4) years or pay an amount of Twelve Thousand Ghanaian Cedis (GHS 12,000) each for violating Covid-19 rules and safety protocols. Everyone expected that the same law was applied to punish the Deputy Trade's Minister Carlos Ahenkorah for putting the public at risk of Covid-19 despite the resignation.

The pure, and selective justice that we witnessed when Covid-19 laws were broken by certain individuals is against our constitution which proffers Freedom and Justice for all Ghanaians. It is instructive for the government and President Akufo-Addo to note that the only way to get the full cooperation of Ghanaians in the fight against Covid-19 is to maintain fairness and equity when putting our laws to test, not the other way round. The government's attitude in the administration of justice could be one of the main reasons why the opposition political parties such as the NDC and many other Ghanaians are behaving the way they do now - portraying gross disrespect for Covisd-19 safety Protocols, and pushing Ghana's Covid-19 case counts upwards.

A recent publication by WHO on July 7, 2020, revealed that Ghana is among the ten (10) countries driving Africa's Covid-19 Cases count higher alongside Nigeria, Algeria, South Africa, etc. (Dzivenu, 2020). This news must be worrying to all Ghanaians. The main cause of rising Ghana's Covid-19 case counts needs to be discovered and addressed fast. One could predict that the Ghanaians attitude cannot be left out in our search. 
INTERNATIONAL JOURNAL OF ACADEMIC RESEARCH IN BUSINESS AND SOCIAL SCIENCES Vol. 10, No. 9, 2020, E-ISSN: 2222-6990 @ 2020 HRMARS

It is more worrying that the government of Ghana through the Ministry of Health has decided not to publish the names of infected persons so that Ghanaians are aware and stay away from them to reduce further spread of the virus. Keeping the status of people who have tested positive for Covid19 secret will provide a fertile ground for infected persons to hide their status from families and friends. Families and friends of the infected persons may contract the virus and in turn, infect others without knowing. This is a danger we could easily avoid in the best interest of Ghana.

\section{Searching for Solutions}

Albert Einstein says, "we cannot solve our problems with the same thinking we used when we created them". By the same logic, Ghanaians cannot continue to behave the same way they we do now in the Covid-19 pandemic era and expect to survive it. It is true that Ghanaians did not bring Covid-19 upon themselves, but they do know how to prevent it and cannot afford to gamble with it. The war against Covid-19 is far from being over, even now that the health experts including WHO are predicting a second wave of the pandemic which could be more spontaneous and devastating than what we are currently witnessing.

Ghanaians who are tempted to assume that the Covid-19 pandemic has already been defeated due to the current decline of Ghana's active case counts and so want to return to their normal lives must reconsider their decision. We should not be in a rush or be deceived that we can return to our normal lives the soonest. Such thinking is misleading and too dangerous to conceive and must be discarded without further delay. We cannot leave the fight against Covid-19 to chance nor risks it. Ghanaians must pursue this deadly pandemic until we get rid of it completely from our land and before any decision is made to return to our normal lives.

The government must be honest with Ghanaians, and not take things for granted if we want to combat this deadly pandemic completely. We need to adopt a collective and practical approach to fighting Covid-19 pandemic, and there is no room for the blame game as is currently the case. Everyone must eschew all forms of partisanship, negativity, double standards, and parochial interest and put the interest of Ghana first.

Ghanaians need a change of attitude towards the virus, adhere to all the recommended safety protocols such as maintaining social distance, regular handwashing with soap or detergent under running water, wearing of shield or nose mask, and covering of mouth when coughing, or sneezing. Every Ghanaian who has tested positive for Covid-19 should disclose their status voluntarily and selfisolate or self-quarantine to avoid putting others or their families and friends at risk of the virus. Your life matters. Stay safe from Covied-19 and protect others. Let us be good citizens and get involved in the fight against the Covid-19 pandemic until we defeat it.

This research contributes immense insights into the Covid-19 literature by providing qualityladen evidence on the research problem from Ghana's perspective. In the current circumstances where Covid-19 continues to pose a bigger threat to human lives, businesses, and livelihoods around the world, this paper could not have come at a better time. Health experts such as WHO will find the contents of this paper useful and can accordingly advise the world on how to properly tackle the Covid-19 pandemic and defeat it in line with the recommendations provided. It is expected that the government of Ghana and the Ghanaians will find this paper useful and apply the recommendation contained herein to mitigate the spread of the Covid-19 pandemic or defeat it completely. The originality of this research stems from its approach/methodology and focus, which differs greatly from what currently exists in the literature. The use of an exploratory approach was suitable for 
INTERNATIONAL JOURNAL OF ACADEMIC RESEARCH IN BUSINESS AND SOCIAL SCIENCES

Vol. 10, No. 9, 2020, E-ISSN: 2222-6990 @ 2020 HRMARS

addressing the research problem accurately by providing detailed evidence on the issues of interest. Finally, not the least, this paper will help researchers who are interested in carrying out investigations on Covid-19 as a research document.

\section{References}

Adebayo, B. (2020). Ghana lifts lockdown, citing improved testing and 'severe' impact on the poor. CNN: https://edition.cnn.com/2020/04/20/africa/ghana-ends-lockdown-intl/index.html

Ansah, M. (2020). Akufo-Addo announces partial lockdown of Accra, Kumasi, Tema to curb COVID-19 spread. Citinewsroom: https://citinewsroom.com/2020/03/akufo-addo-announces-partiallockdown-of-accra-kumasi-tema-to-curb-covid-19-spread/

Ansah, M. (2020). Display dead bodies on TV to show Ghanaians COVID-19 is real - Bagbin. CNR: https://citinewsroom.com/2020/05/display-dead-bodies-on-tv-to-show-ghanaians-covid-19is-real-bagbin/

Anyorigya, D. A. (2020). Declare nationwide lockdown now - GMA to government. Citinewsrrom: https://citinewsroom.com/2020/03/declare-nationwide-lockdown-now-gma-togovernment/

Asante, C. (2017). Read President Nana Akufo Addo's Inaugural Speech. Ghana Celebrities.com: https://www.ghanacelebrities.com/2017/01/08/full-text-read-president-nana-akufo-addosinaugural-speech/

Darwish, S., Ahmed, U., \& Pahi, M. H. (2020). Innovative Work Behavior During COVID-19 for Medical Representative in the Pharmaceutical Industry: Test of a Moderation Model in Bahrain. International Journal of Pharmaceutical Research. 12(4), 1927-

1934. doi.org/10.31838/ijpr/2020.12.04.277

Davlo, E. S. (2020). President Akufo-Addo's 4th address on COVID-19. ABCnewsgh.com: https://www.abcnewsgh.com/full-speech-president-akufo-addos-4th-address-on-covid-19/

Dixon, F. (2020). COVID-19: Full Text of President Akufo-Addo's Speech Announcing Lockdown. GhanaXtra.com: https:/ghanaxtra.com/2020/03/covid-19-full-text-of-president-akufoaddos-speech-announcing-lockdown.html

Dogbevi, E. K. (2020). Ghana confirms the first COVID-19 cases. Ghana Business News: https://www.ghanabusinessnews.com/2020/03/12/ghana-confirms-first-covid-19-cases/

Dzivenu, E. (2020). Ghana Driving Africa's Covid-19 Case Count Higher - WHO. Myjoyonline: https://www.peacefmonline.com/pages/local/health/202007/417954.php

Ghanaweb. (2020). Coronavirus: Local firms to start production of PPEs - Akufo-Addo. https://www.ghanaweb.com/GhanaHomePage/NewsArchive/Coronavirus-Local-firms-tostart-production-of-PPEs-Akufo-Addo-915274

GhanaWeb. (2020). 20\% of Ghanaians don't believe that coronavirus exists - Kojo Oppong-Nkrumah. https://www.ghanaweb.com/GhanaHomePage/NewsArchive/20-of-Ghanaians-don-tbelieve-that-coronavirus-exist-Kojo-Oppong-Nkrumah-1012357

Musungu, N. (2020). President Akufo-Addo announces free water, electricity in Ghana. NairoboNews: https://nairobinews.nation.co.ke/news/president-akufo-addo-announces-free-waterelectricity-in-ghana

Pierre, J. (2020). Full text of Akufo-Addo's speech on partial lockdown. Coronavirus.com.gh: https://coronavirus.com.gh/full-text-of-akufo-addos-speech-on-partial-lockdown/ 
INTERNATIONAL JOURNAL OF ACADEMIC RESEARCH IN BUSINESS AND SOCIAL SCIENCES

Vol. 10, No. 9, 2020, E-ISSN: 2222-6990 @ 2020 HRMARS

Rothan, H. A., \& Byrareddy, S. N. (2020). The epidemiology and pathogenesis of coronavirus disease (COVID-19) outbreak. Journal of Autoimmunity, 109(2020), Article 102433. Academic Press. https://doi.org/10.1016/j.jaut.2020.102433

Shereen, M. A., Khan, S., Kazmi, A., Bashir, N., \& Siddique, R. (2020). COVID-19 infection: Origin, transmission, and characteristics of human coronaviruses. Journal of Advanced Research, 24(2020), 91-98. Elsevier B.V. https://doi.org/10.1016/j.jare.2020.03.005

Sohrabi, C., Alsafi, Z., O’Neill, N., Khan, M., Kerwan, A., Al-Jabir, A., ... Agha, R. (2020). World Health Organization declares global emergency: A review of the 2019 novel coronavirus (COVID-19), 76(2020), 71-76. International Journal of Surgery. Elsevier Ltd.

https://doi.org/10.1016/j.ijsu.2020.02.034

Worldometer. (2020). Covid-19 Coronavirus Pandemic.

https://www.worldometers.info/coronavirus/ 